\title{
IRIBAN DALAM EKONOMI KAMPUNGAN Studi Kasus di Desa Jambu, Mlonggo, Jepara
}

\author{
Siti Hasanah \\ Jurusan Akuntansi \\ Program Studi Perbankan Syariah \\ Politeknik Negeri Semarang \\ hsnpoetry@gmail.com
}

\begin{abstract}
Among villagers of Jambu, in Mlonggo subdistrict of Jepara regency, there is iriban activity that has become a tradition in their daily lives. This routine includes neighborhood meeting on the date of 15th and 30th, participated by men and women as members of the neighborhood association (Rukun Tetangga); the other activities are only participated by the men such as dhiba'an or berjanjen held every Sunday evening, the manaqiban held on the date of 11th and 27th as well as tahlilan held every Thursday night. Iriban activity has become a tradition that is carried out from generation to generation. Yhe reason for the implementation of iriban tradition is to draw the spirit and sympathy of the people to participate in social activities. The implementation of iriban philosophy includes some elements, such as paguyuban (gemeinschaft) and patembayan (gesselschaft) concepts, reciprocity, exchange theory, and togetherness.
\end{abstract}

Key words: village, economy, tradition, neighborhood, religious practices, Jepara, Javanese.

\section{Pendahuluan}

Setiap masyarakat mempunyai suatu kebudayaan yang berbeda dari kebudayaan masyarakat lain. Kebudayaan selalu berhubungan dengan nilai, norma, sikap dan perilaku berpola dari sebagian besar anggota kelompok masyarakat tertentu (Sujarwa, 2001: 18). Masyarakat sebagai suatu sistem hubungan identitas dan kelompok merupakan suatu sistem sosial keseluruhan yang memiliki tradisi budaya dan bahasa yang sama bagi para anggotanya (Keesing, 1981: 74-75). Demikian juga yang terjadi pada masyarakat desa Jambu kecamatan Mlonggo Kabupaten Jepara dengan tradisi iriban yang telah melekat dan mengakar.

Iriban merupakan suatu kegiatan peminjaman uang atau barang kepada anggota yang membutuhkan yang kelak akan dikembalikan pada saat anggota lainnya membutuhkan barang tersebut yang dilaksanakan secara bergantian dari rumah ke rumah berdasarkan hasil undian (Purnomo, 2011: 62). Kegiatan Iriban telah menjadi tradisi dan kegiatan rutin bagi masyarakat desa Jambu, bahkan sudah menjadi suatu kebutuhan. Waktu pelaksanaan tradisi ini sesuai kesepakatan anggotanya baik secara mingguan maupun setiap bulan. Di Kabupaten Jepara, Iriban ini dilaksanakan bagi seluruh unsur masyarakat mulai dari ibu-ibu pengajian, ibu-ibu PKK, remaja karang taruna, pemuda Ansor, bahkan kumpulan bapakbapak. Tradisi iriban menjadi penting bagi masyarakat karena dapat dijadikan sebagai tabungan ketika mereka membutuhkan seperti kebutuhan punya hajat, renovasi rumah, syukuran dan sebagainya.

Kegiatan iriban ini menjadi unik karena tidak semua masyarakat di Jawa Tengah mengenal dan melaksanakannya. Kegiatan serupa yang dikenal masyarakat secara umum dan telah menjadi tradisi adalah kegiatan arisan. Arisan merupakan kegiatan yang umum dilakukan bersamaan dengan pertemuan atau perkumpulan sosial lainnya. Dalam tradisi iriban uang yang dipinjamkan sesuai dengan kemampuan dan kebutuhan para anggotanya sehingga jumlahnya tidak sama, hal ini berbeda 
dengan arisan yang jumlah uang yang disetor harus sama bagi semua anggota. Sebagian besar masyarakat di Jepara melakukan tradisi ini terutama bagi para pekerja atau buruh di perusahaan mebel di kota ukir ini. Iriban biasa dilaksanakan oleh para ibu rumah tangga yang terwadahi dalam organisasi PKK.

Pelaksanan tradisi iriban di Jepara ini secara filosofis meliputi beberapa unsur yaitu unsur silaturrahim karena setiap anggota iriban akan mendapat giliran ketempatan acara sehingga terdapat unsur silaturrahim antara anggota iriban dengan keluarga yang ketempatan, semacam paguyuban (gemeinschaft) di mana terdapat kehidupan kolektif bersama yang anggota-anggotanya diikat oleh hubungan batin yang murni dan bersifat alamiah serta kekal. Dasar hubungannya adalah rasa cinta dan kesatuan batin yang memang telah dikodratkan. Juga terdapat unsur patembayan (gesselschaft) karena bentuk ikatan kegiatan kolektif ini didasari adanya hubungan timbal balik (reciprocity) atau pertukaran, exchange behavior, kebersamaan dalam kelompok sosial yaitu adanya kepentingan bersama yang menyebabkan terbentuknya sebuah kelompok sosial.

Hubungan sosial dalam tradisi iriban ini merupakan interaksi antar individu sebagai hubungan yang dinamis yang terdapat hubungan timbal balik, saling mempengaruhi dan didasarkan pada kesadaran untuk saling menolong. Sodaqoh dan doa juga tidak bisa dipisahkan dari tradisi iriban ini karena setiap anggota akan mendapat kesempatan untuk ketempatan dan memberikan hidangan sekadarnya, selain itu juga para anggota dalam acara iriban ini selalu mendoakan anggota yang ketempatan secara khusus dan seluruh anggota secara umum dengan membaca tahlil, dhiba'an, dan manaqib.

Studi ini menggunakan pendekatan kualitatif untuk meneliti fenomena yang terjadi dalam suatu masyarakat, melalui pengamatan yang diarahkan pada latar belakang dan individu secara holistik dan memandangnya sebagai bagian dari suatu keutuhan, bukan berdasarkan pada variable atau hipotesis (Moleong, 2003: 3). Metodemetode pengumpulan data memanfaatkan non participatory observation dan in-depth interview. Melalui pendekatan kualitatif studi ini dapat memperoleh informasi yang cukup detil mengenai kondisi, situasi dan peristiwa yang terjadi tergantung pada tahapan tujuan yang ingin dicapai. Metode kualitatif digunakan di sini karena peneliti ingin memahami problem dan situasi pemberdayaan ekonomi kampungan melalui kegiatan iriban. Secara rinci studi ini berusaha menjelaskan mengenai pelaksanaan dan tata cara iriban, latar belakang, makna dan perannya dalam pemberdayaan ekonomi di desa.

\section{Pengertian}

Kata iriban, meski tidak memiliki pengertian yang baku dalam kamus bahasa Jawa maupun bahasa Indonesia, memiliki makna yang sangat beragam yang pada intinya adalah sama yaitu ada unsur tolong-menolong dan pinjam-meminjam. Sebagian ada yang memberikan arti iriban sebagai kegiatan peminjaman uang atau barang kepada anggota yang membutuhkan yang kelak akan dikembalikan pada saat anggota lainnya membutuhkan barang atau uang tersebut yang dilaksanakan secara bergantian dari rumah ke rumah berdasarkan hasil undian (Purnomo, 2011: 62). Ada juga yang mengartikan bahwa iriban adalah suatu budaya memberikan bantuan baik berupa finansial maupun tenaga kepada tetangga maupun sanak kerabat (library.walisongo.ac.id).

Selain itu juga terdapat istilah Irbaniq adalah akronim dari kata Iriban (bahasa Jawa) atau semacam arisan yang beroperasi di luar ekonomi formal sebagai sistem lain untuk menyimpan uang, namun "arisan" juga dimaksudkan untuk kegiatan pertemuan yang memiliki unsur 'paksa' karena anggota diharuskan membayar dan datang setiap kali undian akan dilaksanakan (Wikipedia bahasa Indonesia), dan Infaq (bahasa Arab) yang 
berarti pengeluaran sukarela yang dilakukan seseorang, setiap kali ia memperoleh rizki, sebanyak yang ia kehendaki. Iriban juga berarti kegiatan mengumpulkan uang atau barang yg bernilai sama oleh beberapa orang kemudian diundi di antara mereka untuk menentukan siapa yang memperolehnya, undian dilaksanakan di sebuah pertemuan secara berkala sampai semua anggota memperolehnya (www.kompasiana.com).

Lain halnya dengan masyarakat Rahtawu Kudus perbatasan kabupaten Jepara yang mengenal budaya iriban, yaitu kebiasaan untuk membangun rumah jika ada tetangga atau famili yang memerlukannya dengan cara ikut menyumbang bahan-bahan bangunan sesuai kebutuhan. Sumbangan itu disepakati sebagai barang titipan, yang suatu saat akan dikembalikan oleh si penerima sesuai dengan jumlah yang dia terima. Material itu bisa berupa semen, kayu, genting, besi, bata, (selain pasir, sebab pasir mudah didapat di daerah itu), dan tidak boleh berupa uang/tidak boleh diuangkan. Hal ini menjadi langkah antisipasi apabila ada warga yang mengalami kerusakan rumah akibat bencana, mereka bisa dengan cepat mengatasi kebutuhan akan tempat tinggal bagi korban itu. Dengan demikian sistem iriban yang diciptakan oleh para pendahulu desa ini memiliki nilai-nilai yang mulia, bernilai ekonomis, solidaritas, berinvestasi (sebab setiap orang memiliki jaminan untuk membangun atau memperbaiki rumahnya), tidak terikat waktu (karena bencana juga sulit diprediksi), gotong royong, tidak meriba dan tidak mencari keuntungan (sheepindonesia.org).

Mengenai asal-muasal diadakannya iriban ini belum ditemukan siapa pencetus awalnya. Dari beberapa hasil wawancara menunjukkan bahwa Iriban ini sudah dilakukan sejak zaman dulu kala tanpa menyebutkan tahun karena iriban ini telah menjadi warisan tradisi sejak zaman nenek moyang di desa Jambu dan secara umum di
Jepara karena sebagian besar masyarakat Jepara melakukan tradisi iriban seperti ini.

\section{Praktik}

Iriban yang dimaksudkan dalam penelitian ini adalah iriban yang berupa uang bukan berupa barang. iriban yang dilaksanakan oleh msyarakat warga desa Jambu yang dikemas dalam hubungan sosial melalui beberapa kegiatan sosial yang bersifat umum maupun bersifat keagamaan. Pelaksanaan tradisi iriban ini memiliki susunan organisasi di masingmasing kelompok iriban yang biasanya terdiri dari ketua, sekretaris dan bendahara yang dinamakan dengan pengurus harian. Pengurus harian ini bertugas mengkoordinir para anggota yang sepakat melaksanakan tradisi iriban. Sementara sekretaris bertugas membuat surat undangan yang kadang dilaksanakan secara lesan dengan mendatangi rumah para anggota untuk memberikan informasi. Sekretaris ini juga melakukan tugas administrasi yang meliputi pembuatan formulir anggota iriban dan melakukan pencatatan uang yang masuk dan uang yang keluar. Sementara bendahara sebagai tempat pengumpulan uang atau ndokok serta sebagai tempat pengambilan uang yang disebut narik artinya seorang bendahara menyerahkan sejumlah uang kepada anggota yang narik.

Ketika mengawali iriban, sekretaris mencatat jumlah anggota yang ikut tradisi Iriban kemudian dalam acara pertemuan diadakan pengundian untuk menentukan siapa yang narik yaitu yang ketempatan pelaksanaan iriban sesuai dengan urutan. Anggota yang mendapatkan undian nomor satu maka dialah yang pertama kali ketempatan dan menarik dokokan dari para anggota, artinya dia memiliki hutang sejumlah dokokan yang akan dikembalikan pada putaran berikutnya yang disebut dengan istilah nyaur utang. Meskipun nama-nama anggota yang narik sudah ditentukan sesuai hasil undian, terdapat aturan tidak tertulis yang disepakati, bahwa ketika ada salah satu anggota yang punya 
hajat besar seperti mantu, sunatan, ngedekake omah (membangun rumah), boleh mengajukan narik terlebih dahulu meski pun dia belum saatnya narik atau ketempatan.

Dalam tradisi iriban ini istilah ndokok diartikan sebagai menyerahkan sejumlah uang sesuai dengan kemampuan anggota yang meminjamkan uangnya kepada yang narik; dan istilah narik berarti anggota yang ketempatan menerima sejumlah uang hasil dari dokokan dari para anggota. Dari empat kumpulan atau komunitas yang penulis teliti terdapat kebebasan dalam ndokok yaitu sesuai kemampuan. Namun ada beberapa anggota yang memberikan pengumuman kepada para anggota agar ndokok paling besar sejumlah Rp. 50.000 dan ada juga yang memberikan batasan maksimal $\mathrm{Rp}$. 100.000 dan masih ada juga yang membatasi sampai maksimal Rp. 200.000. Hanya jika tidak terdapat informasi batasan ndokok maka para anggota memiliki hak untuk ndokok sebanyak-banyaknya sesuai dengan kemampuan. Para anggota yang memberikan batasan ndokok memberikan alasan keberatan ketika mengembalikan pada saat yang ndokok sedang narik karena harus mengembalikan sejumlah uang yang telah diterimanya, sehingga dalam tradisi ini terdapat unsur mengukur kemampuan masing-masing dalam mengembalikan. Gambar di bawah ini adalah contoh formulir iriban yang dibawa dan disimpan oleh masing-masing anggota. Dalam gambar tersebut terdapat urutan nama anggota berdasarkan hasil undian dengan jumlah anggota 112 orang. Salah satu anggota iriban namanya bapak Muslimin sebagaimana tertulis dalam gambar formulir tersebut yang menunjukkan bahwa Muslimin tidak membatasi jumlah dokokan sehingga tercatat dokokan yang paling besar sejumlah Rp. 400.000. Muslimin mendapatkan urutan ke-38 untuk narik dan ketempatan iriban. Artinya pada iriban sebelumnya muslimin telah ndokok ke anggota nomor ke-1 sampe nomor ke37 dengan total Rp. 2.000.000,- maka ketika dia narik dan ketempatan iriban mendapatkan uang dokokan dari anggota nomor 39 sampai dengan nomor 112 dengan total Rp. 4.510.000,- sehingga jumlah uang yang diterima adalah Rp. 6.510.000,-. Pada kegiatan iriban selanjutnya Muslimin akan nyaur utang kepada anggota nomor-nomor 39-112 sesuai dengan jumlah yang tertera pada catatan formulir dengan total $\mathrm{Rp}$. 4.510.000,-, dengan alur transaksi sebagai berikut 
Gambar 1: Formulir Iriban

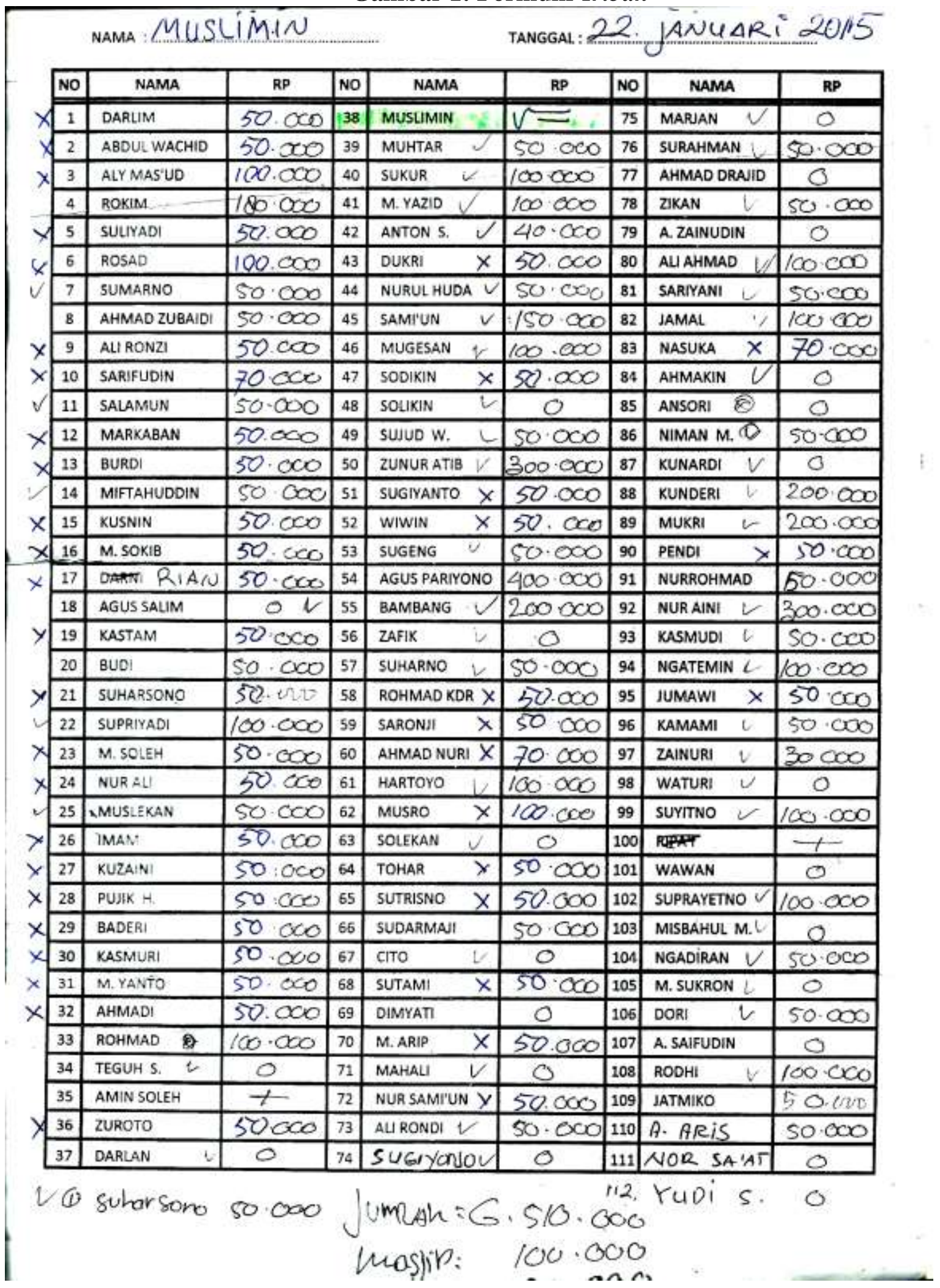




\section{Gambar 2: Alur Transaksi Iriban}
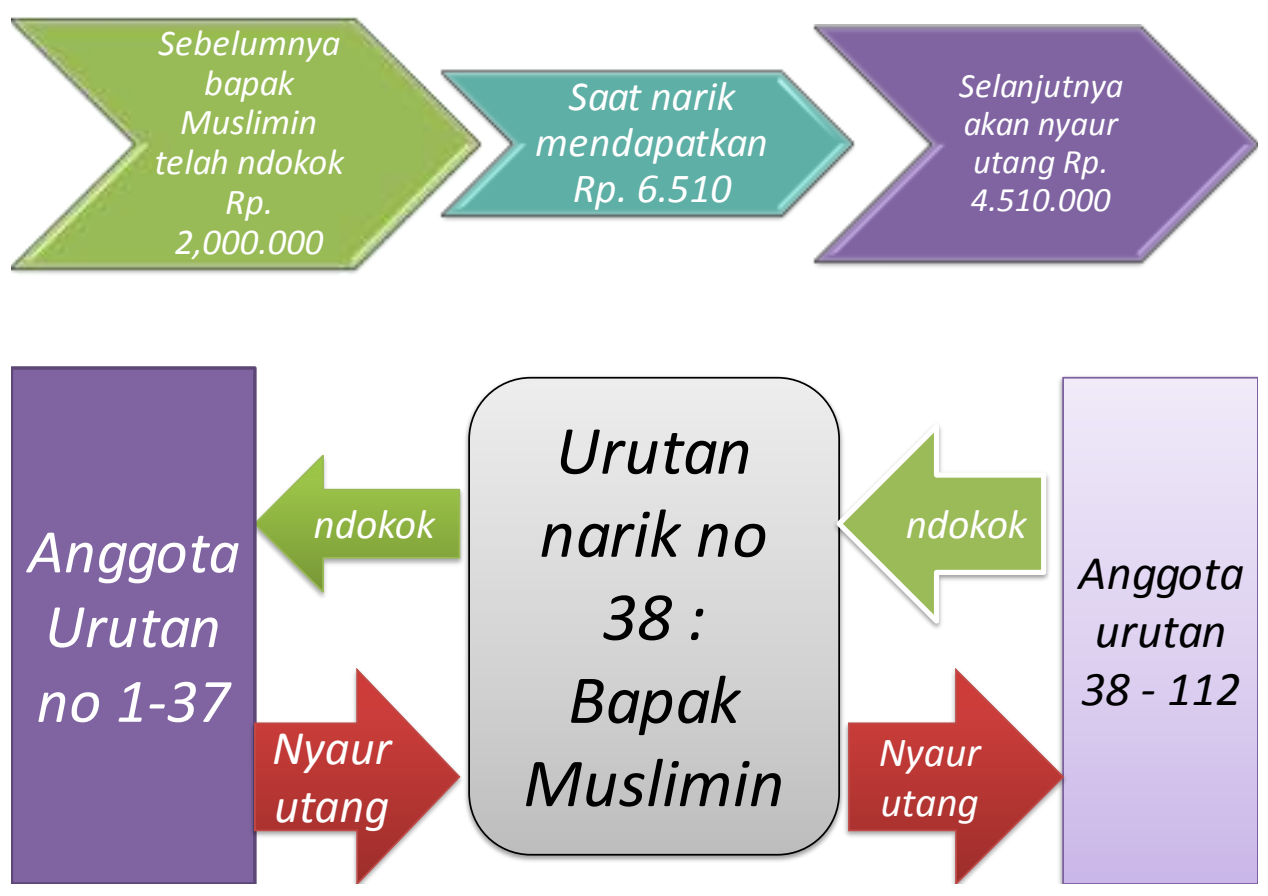

Dalam tradisi iriban ini sekretaris akan membuka acara dan menyiapkan administrasi dengan mencatat nama para anggota yang ndokok maupun yang nyaur utang. Sekretaris mulai memanggil nama anggota kemudian Bagi yang belum narik menjawab dengan jumlah dokokan. Dan bagi yang sudah narik, sekretaris memanggil nama beserta jumlah yang harus dibayar (nyaur utang) dan anggota akan menjawab dengan kata "yo" dengan menyerahkan uangnya. Namun ada beberapa yang datang tapi belum bisa nyaur utang, mereka akan menjawab dengan kata "nganjuk" artinya dia belum bisa bayar dan pada satu atau dua hari berikutnya ketika dia nyaur maka langsung ke anggota yang bersangkutan karena bagi yang nganjuk itu di luar tanggung jawab pengurus. Tanggung jawab pengurus adalah mencatat nama-nama anggota yang nganjuk kemudian diberikan kepada yang narik. Jumlah uang yang diberikan dikurangi Rp. 100.000,- untuk kas Masjid dan Rp. 80.000,- untuk kas iriban - kas iriban adalah milik seluruh anggota iriban yang akan digunakan untuk biaya rekreasi atau wisata ziarah bersama-sama ke makam Waliyulloh.
Setelah prosesi iriban dilaksanakan selanjutnya mulai acara tahlilan atau manaqiban atau berzanjenan atau RT-nan (rapat RT) sesuai dengan rencana dan tujuan pertemuan tersebut. Dalam setiap iriban ini anggota yang ketempatan akan mendapatkan doa secara khusus dari para anggota yang dipimpin oleh kyai sebagai sesepuh dalam acara tersebut. Tuan rumah memberikan segelas teh anget (minuman teh hangat) dan suguhan berupa snack (makanan kecil) yang dibungkus dalam tas atau dus yang berbahan kertas, dengan aneka macam makanan sesuai kemampuan dan selera tuan rumah. Acara yang dimulai pada jam 19.30 WIB atau ba'da isya biasanya selesai jam 21.00 WIB.

\section{Kegiatan Sosial \& Keagamaan}

Tradisi iriban di desa Jambu dilaksanakan sesuai dengan kesepakatan para anggotanya yaitu kesepakatan waktu dan tempat, dan dilaksanakan dengan dibarengi acara tahlilan, dhiba'an atau manaqiban, artinya di masyarakat Mlonggo setiap ada kegiatan sosial ditambah dengan iriban. Kegiatan sosial di desa Jambu yang diisi dengan tradisi iriban adalah sebagai berikut. 


\subsection{Kumpulan RT}

Acara kumpulan RT ini maksudnya adalah pertemuan rutin warga Rukun Tetangga (RT). Kegiatan ini diikuti oleh sejumlah warga RT yang diikuti oleh bapak sebagai kepala keluarga maupun ibu, yang dalam kegiatan ini biasanya dipisah tempatnya. Untuk bapak-bapak tempatnya di teras atau rumah bagian luar dan untuk ibu-ibu tempatnya di rumah bagian dalam. Acara ini dilaksanakan rutin setiap tanggal 15 dan tanggal 30 setiap bulan. Kegiatan ini diikuti oleh sekitar 70125 orang sesuai dengan jumlah warga. Seperti di RT 25 misalnya, acara iriban ini diikuti oleh 70 orang, RT 13 jumlah warganya 125 orang, dilaksanakan pada jam 19.30 WIB atau ba'da isya. Tempatnya telah ditentukan pada saat pengundian di awal sebelum mulai. Jumlah uang yang ditarik biasanya sekitar 5-9 juta rupiah. Susunan acara dalam kumpulan RT ini diawali dengan pembukaan kemudian acara iriban dilanjutkan dengan rapat RT dan dakhiri dengan penutup. Adapun acara teknis iriban sebagaimana yang dijelaskan di atas.

\subsection{Tahlilan}

Tahlilan dilaksanakan secara berjamaah. Tahlil berarti membaca serangkaian surat-surat al-Qur'an, ayatayat pilihan dan kalimah-kalimah dzikir pilihan yang diawali dengan membaca surat alfatihah dengan meniatkan pahalanya untuk para arwah yang dimaksudkan oleh si pembaca atau si empunya hajat dan kemudian ditutup dengan doa. Inti doa dalam acara tahlil adalah memohon kepada Allah SWT agar pahala dari bacaan al-Qur'an dan zikirzikir pilihan itu disampaikan kepada para arwah yang dimaksudkan khususnya dan kepada mukminin mu'minat pada umumnya, serta memohon kepada Allah SWT agar berkenan mengampuni dosadosa mereka (Anis, 2009: 2).

Acara tahlilan bagi masyarakat desa Jambu dilaksanakan rutin setiap minggu pada hari kamis malam jum'at pada jam
19.30WIB atau ba'da isya. Tempatnya juga telah ditentukan pada saat pengundian di awal sebelum mulai. Acara ini hanya diadakan khusus untuk bapak-bapak yang berasal dari warga lintas RT artinya tidak hanya diikuti oleh satu RT saja. Jumlah anggota yang datang biasanya sekitar 100 orang. Adapun jumlah uang yang ditarik biasanya lebih besar dari pada kumpulan RT namun juga diberlakukan syarat dan ketentuan sesuai dengan kesepakatan. Acara tahlilan ini diawali dengan iriban terlebih dahulu baru kemudian dilanjut dengan pembacaan tahlil yang dipimpin oleh seorang kyai desa yang telah ditunjuk oleh tuan rumah atau shohibulbait.

Tujuan acara tahlilan ini untuk mendoakan arwah-arwah anggota keluarga khususnya keluarga yang ketempatan dengan menunjukkan selembar tulisan nama-nama arwah biasanya sampai $10-20$ nama dan secara umum doa tahlil untuk para arwah keluarga para hadirin yaitu jamaah yang datang di acara tahlilan. Bacaan-bacaan tahlilan ini meliputi hadroh/hadiah bacaan surat al fatihah kemudian Surat al-Ikhlas, Surat al-Falaq, Surat an-Nas, Surat al-Baqarah ayat 1 sampai ayat 5, Surat al-Baqarah ayat 163 , Surat al-Baqarah ayat 255, Surat alBaqarah ayat dari ayat 284 sampai ayat 286, Surat al-Ahzab ayat 33, Surat alAhzab ayat 56 dan sela-sela bacaan antara Shalawat, Istighfar, Tahlil da Tasbih

\section{3. Manaqiban}

Di desa Jambu juga ada tradisi pembacaan kitab Manaqib Syekh Abdul Qadir Jailani, yang biasa disebut Manaqiban. Sebelum pembacaan kita Manaqib dimulai, terlebih dahulu diawali dengan bacaan surat al-Fatihah, kemudian pimpinan upacara membacakan doa dan qasidah, yang kemudian diikuti para hadirin, baru setelah itu dibacakan Manaqib Syekh Abdul Qadir Jailani secara bergantian, sebagian demi sebagian sampai tamat. Setiap nama Syekh Abdul Qadir Jailani disebut, maka para hadirin membaca al-Fatihah, dan kalau sampai 
pada pembacaan Laa ilaaha illalloh, Muhammadur Rasululloh, Syekh Abdul Qadir Jailani waliyulloh, radhiyallohu anhu, maka hadirin menirukan membaca radhiyallohu anhu.

Acara manaqiban di desa Jambu ini diawali dengan tradisi iriban yang dilaksanakan pada setiap tanggal 11 dan tanggal 27 pada setiap bulan. Biasanya dilaksanakan pada jam 19.30 WIB atau ba'da isya. Tempatnya juga telah ditentukan pada saat pengundian di awal sebelum mulai.. Acara ini diikuti oleh jamaah yang terbatas khusus jamaah manaqiban yang terbentuk di masingmasing RT sehingga jumlahnya terbatas hanya 27 orang.

\section{4. Berzanjenan}

Acara berzanjenan ini merupakan acara pembacaan kitab maulid al-Barzanji dan al-Diba'i yang biasanya ada sebutan Diba'an. Dalam tradisi maulid ini terdapat inti yaitu kecintaan kepada Nabi Muhammad sebagai sarana wushuliyah menuju kecintaan kepada Allah SWT karena dalam kitab maulid terdapat doktrin tentang Nur Muhammad sebagai pusat dan maksud penciptaan alam dan manusia. Hal ini sebagaimana dikutip dalam Ritual dan Tradisi Islam Jawa (Sholikhin, 2010: 459). Kitab mauled al barzanji ini biasanya dibacakan pada acara-acara peringatan dan perayaan hari kelahiran Nabi Muhammad SAW tanggal 12 Rabi'ul awwal. Namun bagi masyarakat desa Jambu, acara berzanjenan ini dilaksanakan pada setiap malam senin pada jam 19.30 WIB atau ba'da isya. Tempatnya juga telah ditentukan pada saat pengundian di awal sebelum mulai.. Acara ini diikuti oleh jamaah yang terbatas khusus jamaah Berzanjenan yang terbentuk di masingmasing RT sehingga jumlahnya terbatas hanya 30 orang.

\section{Nilai-nilai Mulia}

Dalam tradisi iriban, yang menurut warga masyarakat Jambu sebagai warisan tradisi nenek moyang para pendahulu desa, terdapat beberapa nilai luhur dan mulia sehingga masyarakat masih melestarikan hingga saat ini. Nilai-nilai tersebut adalah sebagai berikut :

\section{1. Solidaritas}

Dalam tradisi iriban ini terdapat hubungan sosial yang mencerminkan nilainilai solidaritas sosial. Hubungan sesama anggota memiliki rasa kepercayaan yang tinggi antara sesama. Solidaritas ini menekankan pada keadaan hubungan antar individu sebagai anggota iriban dan kelompok seperti kumpulan $R T$ nan jamaah manaqiban, tahlilan, berzanjenan didasari adanya keterikatan bersama dalam kehidupan dengan didukung nilai-nilai moral dan kepercayaan yang hidup dalam masyarakat. Wujud nyata dari hubungan bersama akan melahirkan pengalaman emosional, sehingga memperkuat hubungan antar mereka. solidaritas sosial ini merupakan perasaan yang secara kelompok memiliki nilai-nilai yang sama atau kewajiban moral untuk memenuhi harapan-harapan peran (role expectation) (Nasution, 2010). Oleh karenanya prinsip solidaritas sosial masyarakat meliputi: saling membantu, saling peduli, saling bekerjasama, saling membagi hasil panen, dan bekerjasama dalam mendukung pembangunan di desa baik secara keuangan maupun tenaga dan sebagainya (Lawang, 1994: 181).

Masyarakat desa Jambu memiliki tingkat solidaritas yang tinggi, karena kebanyakan dari mereka selalu mencoba meluangkan waktu agar dapat bertemu dengan para tetangganya walaupun hal tersebut hanya saling menyapa. Mereka selalu mencoba memupuk rasa persudaraan antara warga dengan mengadakan berbagai macam kegiatan-kegiatan yang dapat mempertemukan antara warga satu dengan warga lain. Solidaritas ini merupakan alat untuk memupuk rasa persaudaraan antar anggota masyarakat. Dengan adanya solidaritas masyarakat menjadi lebih bisa mengerti keadaan sesama warga, saling tolong menolong antara warga masyarakat. 


\section{2. Gotong Royong}

Dalam iriban mampu mewujudkan kegiatan gotong royong yang menjadi nilai bagi masyarakat desa Jambu karena mengedepankan rasa kebersamaan. Dalam masyarakat jawa muncul pepatah "naliko rekoso dipikol bareng-bareng." Pepatah ini mempunyai arti yang luas dalam tatanan kehidupan masyarakat. Sebagai mahluk sosial dituntut untuk memiliki rasa empati terhadap mahluk sosial yang lain. Kondisi ini juga didasarkan atas hakekat manusia tidak bisa hidup sendiri. jadi setiap individu membutuhkan individu yang lain dalam memenuhi kebutuhan seperti dalam istilah sosiologi manusia itu mempunyai sifat Gregariousness yaitu naluri seorang manusia untuk cenderung bergaul dengan orang lain, menjalin ikatan persahabatan, dan membentuk suatu kelompok sosial (Narwoko, 2007: 62).

Masyarakat yang bergabung dalam wadah organisasi sosial ini memiliki proses yang penting yang dinamakan proses eksistensial yaitu proses kesadaran diri yaitu sejauh mana orang sadar akan apaapa yang terjadi padanya, akan kenyataan sosial, akan hubungannya dengan orangorang lain dan sebagainya. Proses eksistensial ini meliputi proses yang berhubungan dengan persepsi terhadap dunia luar, interaksi antara orang dan lingkungan, interaksi antara orang dengan orang yang menghasilkan kepuasan/ keterlibatan. Penerimaan diri serta perwujudan diri. Proses eksistensial ini penting untuk memadukan individu dalam organisasi. Jika proses ini diabaikan akan berpengaruh kurang baik terhadap orang yang bekerja dalam kelompok maupun mutu pekerjaan dalam organisasi. Proses utama pada tingkat antar priibadi adalah proses empati, proses satu orang mengulurkan tangan ke orang lain dan mengadakan suatu hubungan (Udai, 1996: 4).

\section{3. Investasi}

Tradisi iriban telah cukup mengakar di dalam masyarakat desa Jambu. Tradisi ini dapat dijumpai hampir di setiap daerah di Jepara dan di semua kalangan, baik masyarakat kelas bawah, menengah, maupun atas. Hanya besaran nilai iriban yang diterima yang berbeda-beda. Selain memperkuat hubungan sosial, perputaran uang di iriban juga menggerakkan konsumsi dan investasi kecil-kecilan. Iriban menjadi salah satu media untuk menjaga kebersamaan dengan kerabat atau relasi. Selain memiliki fungsi interaksi sosial yang kuat, iriban juga mempunyai fungsi ekonomi, yaitu "iso dicagerke" artinya bias menjadi sarana tabungan, sehingga tradisi iriban bertahan hingga kini. Iriban ini merupakan fenomena sosial yang banyak dijumpai di berbagai lapisan masyarakat dari lingkungan terdekat, seperti rukun tetangga, rukun warga, jamaah pengajian hingga lingkungan kerja. Kedekatan masyarakat melalui kegiatan iriban ini tergambar dari jumlah iriban yang diikuti. Satu orang anggota bias mengikuti 1-5 kelompok iriban yang dilaksanakan setiap minggu atau dua minggu sekali. Sebagian responden mengungkapkan bahwa motif dalam mengikuti iriban adalah rasa semangat dalam mengikuti kegiatan-kegiatan sebagai bentuk interaksi sosial

\section{4. Hubungan Timbal Balik}

Dalam iriban terdapat proses pertukaran atau timbal balik sebagaimana dalam aktifitas ekonomi yaitu ada yang ndokok (memberikan pinjaman) dan ada yang narik (mengambil uang yang telah dipinjamkan). Unsur Resiprositas atau pertukaran timbal balik ini berdasarkan gagasan yang sederhana yakni bahwa orang harus membantu mereka yang pernah membantunya atau setidak-tidaknya jangan merugikannya. Uang dokokan dalam iriban ini sesuai dengan konsep resiprositas dimana barang atau jasa yang dipertukarkan mempunyai nilai yang sebanding. Dalam pertukaran tersebut 
disertai pula dengan kapan pertukaran itu berlangsung, kapan memberikan, menerima, dan mengembalikan.

Resiprositas macam ini disebut dengan resiprositas sebanding yang mempunyai ciri dengan adanya normanorma atau aturan-aturan atau sanksisanksi sosial untuk mengontrol individuindividu dalam melakukan transaksi. Bila individu melanggar perjanjian resiprositas, ia akan mendapat hukuman berupa tekanan moral seperti dikucilkan oleh masyarakat. Ciri lain dari resiprositas sebanding adalah keputusan untuk melakukan kerja sama resiprositas berada di masing-masing individu. Kerja sama ini muncul karena adanya rasa kesetiakawanan di kalangan mereka sehingga terlembaga. Meskipun resiprositas tersebut muncul sebagai perwujudan dari solidaritas sosial, tetapi berbeda dengan resiprositas umum karena kesetiakawanan yang ditampilkan dalam resiprositas sebanding tidak penuh, yaitu individu tetap pada apa yang didistribusikan kepada partnernya akan kembali lagi atau antar individu tidak mau rugi.

Resiprositas sebanding berada di antara resiprositas umum dan resiprositas negatif. Jika resiprositas sebanding bergerak ke arah resiprositas umum, maka hubungan sosial yang terjadi mengarah ke hubungan kesetiakawanan dan hubungan personal yang intim (Sahlins, 1974: 194). Sebaliknya apabila bergerak ke arah resiprositas negatif, contohnya jual beli, hubungan yang terjadi bersifat tidak setia kawan, yakni masing-masing pihak saling berusaha mendapatkan keuntungan dari lawannya. Secara umum dapat dikatakan bahwa fungsi resiprositas adalah membina solidaritas sosial dan menjamin kebutuhan ekonomi sekaligus mengurangi resiko kehilangan yang dipertukarkan. Namun demikian, fungsi sosial tersebut dapat rusak apabila salah satu pihak tidak konsekuen dalam mengembalikan (Sairin, dkk; 2002: 55-58)

\subsection{Tidak Riba atau Mencari Keuntungan \\ Tidak ada unsur riba dalam tradisi} iriban ini karena uang yang didokok juga akan kembali ketika narik tanpa ada suatu tambahan sedikit pun meskipun terdapat durasi waktu yang berbeda ketika ndokok dan narik.kegiatan ini menunjukkan bahwa landasan iriban ini bukan landasan mendapatkan untung akan tetapi didasari pada rasa solidaritas sosial yaitu ta'awun atau tolong menolong antara anggota.

Pinjaman tanpa bunga ini disebut alQard al-Hasan pinjaman yang tidak terikat, tanpa bunga dan tanpa commitment fee (Karnaen, 1997:62). Dalam literatur fikih, transaksi al-Qard al-Hasan tergolong transaksi kebajikan atau tabarru' atau ta'awuni. Dengan kata lain al-Qard al-Hasan adalah pemberian pinjaman tanpa mengharapkan imbalan tertentu. Muhammad 'Ali al-Sabuni menafsirkan alQard al-Hasan memberi dan membelanjakan harta pada jalan kebaikan semata-mata untuk mendapatkan ridha Allah dan meninggikan kalimah tauhid sama ada untuk medan jihad ataupun sebagainya dari perkara yang baik. Maka balasan yang akan diterimanya ialah Allah akan melipat gandakan ganjaran pahalaNya (al-Sabuni, 1986:156).

\section{6. Silaturrahim, Sodaqoh dan Doa}

Dalam ranah interaksi sosial, iriban berfungsi sebagai media untuk saling kunjung, berbagi informasi, dan sebagai media kerukunan. Dalam lingkup rukun tetangga, misalnya, iriban menjadi ajang berkumpulnya masyarakat untuk saling sapa dan berbagi informasi, saling mendoakan, saling memberikan sodaqah dengan member suguhan pada saat ketempatan. Semangat dalam silaturrahim ini terbentuk dengan adanya iriban. Oleh karenanya iriban dikemas dengan kegiatan keagamaan menjadi semarak dan semangat bagi masyarakat. Jika budaya iriban ini dihilangkan bisa jadi kegiatan keagamaan terasa kering bagi masyarakat yang menghendaki keguyuban. Dalam hal ini 
harus padu antara budaya dan agama. Masyarakat desa Jambu ini mengarah pada masyarakat agraris yang cenderung menekankan agama simbolis (agama plus budaya spiritual), berbeda dengan masyarakat industri yang membutuhkan lebih banyak agama substantif (agama yang syariatnya dilaksanakan secara konsekuen) dan masyarakat pasca industri memerlukan agama substanstif dan agama simbolis (Kuntowijoyo, 2001:219). Konsepsi Geertz (1992: 87-125) tentang agama sebagai pola bagi tindakan (Pattern for behaviour), agama merupakan pedoman yang dijadikan sebagai kerangka interpretasi tindakan manusia. Selain itu agama juga merupakan pola dari tindakan, yaitu sesuatu yang hidup dalam diri manusia yang tampak dalam kehidupan kesehariannya. Di sini agama dianggap sebagai bagian dari sistem kebudayaan (Geertz,1992: 8-9).

\section{7. Etos Kerja}

Masyarakat desa Jambu rata-rata mengikuti tiga kelompok iriban yang diadakan setiap minggu. Kondisi ini menuntut para anggota iriban untuk menyisihkan uangnya untuk ndokok pada iriban. Rata-rata mayarakat memiliki penghasilan dari petani, penjual ikan di pasar dan nelayan. Ketika musim rendeng (hujan) datang maka akan berpengaruh terhadap ndokokan iriban. Kondisi tersebut menyebabkan masyarakat memiliki semangat dan etos kerja untuk mendapat uang yang akan digunakan untuk memenuhi kebutuhan sehari-hari serta untuk mengikuti iriban.

Etos kerja ini bukan hanya sekadar bergerak atau bekerja melainkan sebuah kepribadian yang bermuatan moral dan manjadikan landasan moralnya sebagai cara mengisi dan menggapai makna hidup, menggapai kebahagiaan dunia dan akherat. Sehingga etos kerja berkaitan dengan senyawa dan semangat, kejujuran, kepiawaian atau profesiaonal dalam bekerja (Tasmara, 2008: 24).

\section{Pemberdayaan Ekonomi}

Tradisi iriban yang telah dilestarikan masyarakat Desa Jambu merupakan dinamika ekonomi yang berbasis kearifan lokal. Iriban ini dijadikan sebagai sarana tabungan yang memiliki unsur tolong menolong dengan tetangga sekitar. Investasi bergaya kampungan ini sudah menjadi suatu kebutuhan yang dijadikan sebagai jaminan yang diistilahkan warga desa dengan kata "cageran" sehingga masyarakat memandang iriban ini menjadi sangat penting. Dinamika ekonomi berbasis lokal ini memiliki peran untuk pemberdayaan.

Secara umum Pemberdayaan masyarakat adalah sebuah konsep pembangunan ekonomi yang merangkum nilai-nilai sosial. Konsep ini mencerminkan paradigma baru pembangunan, yakni yang bersifat "people centred, participatory, empowering, and sustainable" (Chambers, 1995). Konsep ini lebih luas dari hanya semata-mata memenuhi kebutuhan dasar (basic needs) atau menyediakan mekanisme untuk mencegah proses pemiskinan lebih lanjut (safety net), yang pemikirannya belakangan ini banyak dikembangkan sebagai upaya mencari alternatif terhadap konsep-konsep pertumbuhan di masa yang lalu. Konsep ini berkembang dari upaya banyak ahli dan praktisi untuk mencari apa yang disebut sebagai alternative development, yang menghendaki inclusive democracy, appropriate economic growth, gender equality and intergenerational equaty" (Kartasasmita, 1997).

Namun dalam tradisi iriban ini memiliki unsur pemberdayaan yang sejalan dengan konsep pemberdayaan ekonomi menurut Sumodiningrat (1999) yaitu perekonomian rakyat adalah perekonomian yang diselenggarakan oleh rakyat. Perekonomian yang diselenggarakan oleh rakyat adalah perekonomian nasional yang berakar pada potensi dan kekuatan masyarakat secara luas untuk menjalankan roda perekonomian mereka sendiri. Pemberdayaan ekonomi rakyat 
adalah usaha untuk menjadikan ekonomi yang kuat, besar, modern, dan berdaya saing tinggi dalam mekanisme pasar yang benar. Karena kendala pengembangan ekonomi rakyat adalah kendala struktural, maka pemberdayaan ekonomi rakyat harus dilakukan melalui perubahan struktural. Perubahan struktural yang dimaksud adalah perubahan dari ekonomi tradisional ke ekonomi modern, dari ekonomi lemah ke ekonomi kuat, dari ekonomi subsisten ke ekonomi pasar, dari ketergantungan ke kemandirian. Langkah-langkah proses perubahan struktur, meliputi: a) pengalokasian sumber pemberdayaan sumberdaya; b) penguatan kelembagaan; c) penguasaan teknologi; dan d) pemberdayaan sumberdaya manusia.

Pemberdayaan ekonomi rakyat, tidak cukup hanya dengan peningkatan produktivitas, memberikan kesempatan berusaha yang sama, dan hanya memberikan suntikan modal sebagai stumulan, tetapi harus dijamin adanya kerjasama dan kemitraan yang erat antara yang telah maju dengan yang masih lemah dan belum berkembang. Kebijakannya dalam pembedayaan ekonomi rakyat adalah: a) pemberian peluang atau akses yang lebih besar kepada aset produksi (khususnya modal); b) memperkuat posisi transaksi dan kemitraan usaha ekonomi rakyat, agar pelaku ekonomi rakyat bukan sekadar price taker; c) pelayanan pendidikan dan kesehatan; d) penguatan industri kecil; e) mendorong munculnya wirausaha baru; dan f) pemerataan spasial. Kegiatan pemberdayaan masyarakat mencakup: a) peningkatan akses bantuan modal usaha; b) peningkatan akses pengembangan SDM; dan c) peningkatan akses ke sarana dan prasarana yang mendukung langsung sosial ekonomi masyarakat lokal.

Upaya memberdayakan masyarakat dapat dilihat dari tiga sisi, yaitu (Sumodiningrat, 2002) pertama, menciptakan suasana atau iklim yang memungkinkan potensi masyarakat berkembang (enabling). Di sini titik tolaknya adalah pengenalan bahwa setiap manusia, setiap masyarakat, memiliki potensi yang dapat dikembangkan. Artinya, tidak ada masyarakat yang sama sekali tanpa daya, karena jika demikian akan sudah punah. Pemberdayaan adalah upaya untuk membangun daya itu, dengan mendorong, memotivasikan, dan membangkitkan kesadaran akan potensi yang dimilikinya serta berupaya untuk mengembangkannya.

$\begin{array}{rcr}\text { Kedua, memperkuat } & \text { potensi atau } \\ \text { daya yang } & \text { dimiliki } & \text { masyarakat } \\ \text { (empowering). } & \text { Dalam } & \text { rangka ini }\end{array}$
diperlukan langkah-langkah lebih positif, selain dari hanya menciptakan iklim dan suasana. Perkuatan ini meliputi langkahlangkah nyata, dan menyangkut penyediaan berbagai masukan (input), serta pembukaan akses ke dalam berbagai peluang (opportunities) yang akan membuat masyarakat menjadi berdaya. Pemberdayaan bukan hanya meliputi penguatan individu anggota masyarakat, tetapi juga pranata-pranatanya. Menanamkan nilai-nilai budaya modern, seperti kerja keras, hemat, keterbukaan, dan kebertanggungjawaban adalah bagian pokok dari upaya pemberdayaan ini. Demikian pula pembaharuan institusiinstitusi sosial dan pengintegrasiannya ke dalam kegiatan pembangunan serta peranan masyarakat di dalamnya. Yang terpenting disini adalah peningkatan partisipasi rakyat dalam proses pengambilan keputusan yang menyangkut diri dan masyarakatnya. Oleh karena itu, pemberdayaan masyarakat amat erat kaitannya dengan pemantapan, pembudayaan, pengamalan demokrasi.

Ketiga, memberdayakan berarti pula melindungi. Dalam proses pemberdayaan, harus dicegah yang lemah menjadi bertambah lemah, oleh karena kekurangberdayaan dalam menghadapi yang kuat. Oleh karena itu, perlindungan dan pemihakan kepada yang lemah amat mendasar sifatnya dalam konsep pemberdayaan masyarakat. Melindungi tidak berarti mengisolasi atau menutupi 
dari interaksi, karena hal itu justru akan mengerdilkan yang kecil dan melunglaikan yang lemah. Melindungi harus dilihat sebagai upaya untuk mencegah terjadinya persaingan yang tidak seimbang, serta eksploitasi yang kuat atas yang lemah. Pemberdayaan masyarakat bukan membuat masyarakat menjadi makin tergantung pada berbagai program pemberian (charity). Karena, pada dasarnya setiap apa yang dinikmati harus dihasilkan atas usaha sendiri (yang hasilnya dapat dipertukarkan dengan pihak lain).

Dengan demikian tujuan akhirnya adalah sebagaimana tujuan dalam tradisi iriban yang secara implisit menunjukkan upaya untuk memandirikan masyarakat lokal, memampukan, dan membangun kemampuan untuk memajukan diri ke arah kehidupan yang lebih baik secara berkesinambungan.

\section{Simpulan}

Kegiatan iriban ini menjadi salah satu dinamika ekonomi perkampungan yang dapat dijadikan sebagai tabungan atau investasi berbasis sosial. Anggota yang narik iriban selain berdasarkan pada hasil urutan undian juga mentolerir munculnya kebutuhan yang mendesak seperti kebutuhan untuk membangun rumah, untuk mantu/walimahan dan khitanan ataupun untuk kebutuhan lainnya seperti bencana dan sejenisnya. Tradisi iriban yang sarat dengan muatan nilai-nilai luhur dan mulia ini mampu mewujudkan kemandirian dalam mengelola dana yang bersumber dari masyarakat dan dikelola sesuai kebutuhan masyarakat. Dinamika ekonomi dalam iriban ini berdampak pada perilaku-perilaku ekonomi yang positif yang menjauhkan dari jeratan ekonomi ribawi yang bersifat rakus duniawi. Demikian ini karena nilai-nilai mulia telah dilestarikan seiring dengan lestarinya tradisi iriban yang lebih menekankan pada sifat tolong menolong, gotong royong, solidaritas sosial dan seterusnya. Nilai-nilai yang muncul dalam dinamika ekonomi kampungan ini dapat dijadikan sebagai rujukan nasional karena perilaku ekonomi berbasis lokal ini mampu menciptakan karakter yang baik.

\section{Daftar Pustaka}

Al-Sabuni, Muhammad 'Ali. 1986. Safwah al-Tafasir, c. 5, j. 1. Beirut: Dar alQalam.

Anis, Madchan KH. 2009. Tahlil dan Kenduri Tradisi Santri dan Kyai. Yogyakarta: Pustaka Pesantren.

Chambers, Robert. 1996. PRA: Memahami Desa Secara Partisipatif. Yogyakarta: Kanisius.

Geertz, Clifford. 1992. Kebudayaan dan Agama. Yogyakarta: Kanisius.

Karnaen, A. Perwaatmaja dan M. Syafii Antonio. 1992. Apa dan Bagaimana Bank Islam, c. 1.Yogyakarta: Dana Bakti Wakaf.

Keesing, Roger M. 1981. Antropologi Budaya, Suatu Perspektif Kontemporer. Jakarta: Erlangga.

Kuntowijoyo. 2001. Muslim tanpa Masjid. Bandung: Mizan.

Lawang, Robert M.Z. 1994. Teori Sosiologi Klasik dan Modern. Jakarta: PT. Gramedia Pustaka Utama.

library.walisongo.ac.id.

Moleong, Lexy J. 2003. Metode Penelitian Kualitatif. Bandung: Remaja Rosdakarya.

Narwoko, J. Dwi Bagong Suyanto. 2007. Sosiologi Teks Pengantar dan Terapan. Jakarta: Kencana.

Nasution, Zulkarnain. 2010. Konflik dan Lunturnya Solidaritas Sosial Masyarakat Desa (Online). (http://berkarya.um.ac.id/2010/02/05/ konflik-dan-lunturnya-solidaritassosial-masyarakat-desa-transisi-olehzulkarnain-nasution) diakses pada tanggal 25 Julii 2016 jam 20.00 WIB.

Purnomo, H.; Irawati, R.H.; Melati; eds. 2011. Perjalanan Industri Kecil Mebel Outdoor Manunggal Jati Sinanggul Mlonggo Jepara. Bogor: 
Center for International Forestry Research (CIFOR).

Sahlin, Marshall. 1976. Stone Age Economics. London: Tavistock Publication.

Sairin, Sjafri dkk. 2002. Pengantar Sosiologi Ekonomi. Yogyakarta: Pustaka Pelajar.

Sholikhin, Muhammad KH. 2010. Ritual dan Tradisi Islam Jawa. Jakarta: Suka Buku.

Sujarwa. 2001. Manusia dan Fenomena Budaya Menuju Perspektif Moralitas Agama. Yogyakarta: Pustaka Pelajar.

Sumodiningrat, Gunawan. 1999. Pemberdayaan Masyarakat dan Jaringan Pengaman Sosial. Jakarta: PT Gramedia Pustaka Utama.

Tasmara, Toto KH. 2008. Membudayakan Etos Kerja Islami. Jakarta: Gema Insani.

Udai, Pareek. 1996. Perilaku Organisasi, Pedoman Ke Arah Pemahaman Proses Komunikasi antar Pribadi dan Motivasi Kerja. Jakarta: Pustaka Binaman Pressindo.

http://cdn.sheepindonesia.org/id/buku/buku 1/files/search/searchtext.xml diakses pada tanggal 30 Juli 2016 jam 22.00 WIB.

www.kompasiana.com/icha_nors/irbaniqmanajemen-input-sarana-prasaranapaud-berbasis-

masyarakat_5520315c813311186e9d e95c diakses pada tanggal 21 Julii 2016 jam 10.00 WIB.

Para informan: Ibu Titik, Ibu Zulaikhah, Ibu Mustiri, Bapak Muslimin, Bapak Muslim, Mbah Kasmudi, Mbah Badri. Wawancara dilakukan pada bulan Juli 2016. 